\title{
Studies on Chemical Weed Control in Wheat (Triticum aestivum L.) - A Review
}

\author{
Laxman Somanath Vyvahare* and Pratap Jambuvant Khose
}

Department of Agronomy, Lovely Professional University, Jalandhar, Punjab, India

*Corresponding author

\section{A B S T R A C T}

Keywords

Weed flora,Weed management practices, weed density

Article Info

\section{Accepted:}

17 January 2021

Available Online:

10 February 2021
Wheat (Triticum aestivum L.) is one of the main cereal crop cultivated in India. It is widely cultivated, produced and used throughout the world. Wheat is the most popular staple food for human consumption. Separate application of herbicide is not effective control grassy and broadleaf weeds are but the combination of herbicides which give better result to control mixed weed flora in wheat crops. The continuous use of herbicides such as Isoproturon has caused resistance to the herbicides in Phalaris minor in Punjab and Haryana but, it has also effectively control by rotations of herbicides (Tank mix).

\section{Introduction}

Wheat (Triticum aestivum L.) is one of the main cereal crops in India. It is widely cultivated, produced and used throughout the world. Of all grain crops, wheat is the most popular staple food for human consumption. Belonging to the family of the Poaceae, it is an annual crop of self-pollination.

It is a photographic crop having periodically long day scenario. It is grown during the Rabi season in temperate regions and also at high altitudes in tropical climatic zones in winter. It is a cereal of choice that is considered the backbone of food security for a large number of countries. Wheat is sown from the month of September to December in various states of India and harvesting is done from February to May. The winter temperature when the Sowing is to be done should range from 10 to 15 degree Celsius and at the time of harvesting it should be from 21 to 26 degree Celsius. Wheat is considered as a cash crop because gives very good yield.

\section{Weed flora associated with wheat}

Amare et al., (2014) observed weed flora 83.3 $\%$ were broadleaved while $16.6 \%$ were 
grasses. The grasses like Avena Fatua L., Phalaris para a L. and Broad leaf weed like Cayluseaa byssinica Meisn, $C$. trigyna $L$, Chenopodium album L., Corrigoialac apensis Wild, Guizotia scabra(Vis)Chiov, Oxalis latifolia HBK, Polygonumne palenseL., Raphanus raphanistrum L., spergula arvensis L., Taget esminuta $L$.

Jabran et al., (2012) at Pakiatan observed the weed flora of the experimental site comprised of both narrow and broad leaved weeds such wild oat (Avena fatua L.), canary grass (Pharalis minor Retz.), lambsquarters (Chenopodium album L.), fathen (Chenopodium murale L.), blue pimpernel (Anagallis arrensis L.) and swine cress (Cronopus didymus L.).

Punia et al., (2017) at Hisar was observed weed flora in all, 21 weed species (4 grassy and 17 broad-leaf) were found to infest wheat fields in Haryana. In grassy weeds like Phalaris minor, Avena ludoviciana, Poa annua, Polypogon monspliensis and broad leaf weeds like Chenopodium album, Chenopodium murale, Rumex dentatus, Rumex spinosus, Coronopus didymus, Anagallis arvensis, Medicago denticulate, Melilotus indica, Malva parviflora, Convolvulus arvensis, Cirsium arvense, Vicia sativa, Trigonella polycerata. Asphodelus tenuifolius, Fumaria parviflora, Pluchea lanceaolata, Carthamus oxycantha.

Joshi et al., (2017) at Rajmata Vijyaraje Scindia Krishi Vishva Vidyalaya, Gwalior, Madhya Pradesh observed was recorded the complex weed flora of the experimental field comprised of grassy weeds as Phalaris minor, Cyperus rotundus and broad-leaved weeds as Chenopodium album, Spergula arvensis, Convolvulus arvensis etc. Singh et al., (2017) at Jabalpur (Directorate of weed research), Madhya Pradesh observed weed flora observed was Lathyrus sativus, Vicia sativa,
Chenopodiumalbum, Medicago denticulata and Melilotus alba among broad-leaf and Avena sp. ( wild oat) and Phalaris minor among grasses.

Sahu et al., (2018) at Krishi Vigyan Kendra, Banka, Bihar was reported that weed density of two grassy weeds, viz. Phalaris minor and Cynodondactylon and five broad-leaved weeds, viz. Chenopodium album, Oxalis purpurea, Anagallis arvensis, Medicago denticulata and Rumex dentatus.

Yadav et al., (2019) at Hisar was observed Weed flora of the experimental field mainly included Phalaris minor Retz. among grassy weeds, and Lathyrus aphaca L., Coronopus didymus L., Vicia sativa L., Medicago denticulate L., Melilotus indica L. and Anagallis arvensis L. among broad leaf weeds.

Mitra et al., (2019) Uttar Banga Krishi Viswavidyalaya, Pundibari, Coochbehar, West Bengal wae observed that weeds found in the field were Polygonumpersicaria, Polygonum pensylvanicum, Polygonum hydropiper, Polygonum orientale, Chenopodium album, Physalis minima, Oxalis corniculata, Portulaca oleracea, Gnaphalium luteo-album, Centella asiatica and Cronopus didymus. Variousspecies of Polygonum was dominant in all the stagesof crop growth.

\section{Crop weed competition}

Singh et al., (2013) The crop weed competition was markedly reduced by weed control treatments as is evident from the significant decrease in weed population, dry matter accumulation, weed killing efficiency, weed control efficiency and weed control index by $6.1 \%, 41 \mathrm{~g} / \mathrm{m}^{2}, 38.1 \%, 67.4 \%,-23.5 \%$ respectively (Singh and Saxena, 2013).

Plots kept weed free up to 30, 45 and 60 DAS and weedy check up to 15 DAS also resulted 
in significant improvement in all growth and yield attributes and recorded at par with that of weed free check up to harvest. Weedy check for initial 30, 45 and 60 DAS and weed free up to 15 DAS recorded at par with weedy check up to harvest. This indicated that unchecked weeds beyond 15 DAS and weed free condition at early stage (up to 15 DAS) failed to check crop weed competition, which was detrimental to cumin growth.

Sandhu et al., (2016) the increase in yield was due to less weed competition among these treatments are reduced weed population 2.2 weeds $/ \mathrm{m}^{2}$.

Saha et al., (2016) to attain economic wheat yield, weeds must be removed during critical period of competition which falls in between 0 to 30 days of sowing.

Galon et al., (2019) the weed control methods of the crop weed competition in the period between 11 to 21 days of crop emergence which is wheat grain yield loss competing with ryegrass reached $59 \%$ when grown with ryegrass.

Hussein et al., (2020) a weed control percentage of $88.35 \%$ and gave the lowest dry weight for the weed reached 35.6 g.m ${ }^{-2}$ compared with the comparison treatment, which reflected positively on increasing the average plant height $(102.3 \mathrm{~cm})$, number of tillers (146.8 tillers $\left.\mathrm{m}^{-2}\right)$, and the spike length $(10.1 \mathrm{~cm})$, which caused an increase in the grain yield by $26 \%$.

\section{Yield reduction in wheat due to weeds}

Khan and Haq, (2002) Weeds can incur a grain yield loss of $48 \%$ in wheat.

Hussain et al., 2015; Fahad et al., 2015) However, the magnitude of weed-related losses depends on the type and density of a particular weed species, its time of emergence, and the duration of the interference.

Oad et al., (2007) the weeds exhibit the economic yield losses to the wheat crop which may range from $24-39.95 \%$.

Kumar et al., (2011) Weeds caused $55.7 \%$ reduction in wheat grain yield.

Kumar et al., (2013) Weeds reduced grain yield of wheat by $59.3 \%$.

Bharat et al., (2012) weeds growth caused $40.3 \%$ reduction in grain yield of wheat.

Malik and Yadav (2013) Weeds allowed growing throughout the crop seasons resulted into 42.9 to $45.1 \%$ reduction in the grain yield of wheat.

Amare (2014) weed growth throughout the crop growth caused a yield reduction 57.6 to $73.2 \%$.

Singh et al., (2015) The average yield losses caused by weeds in different wheat growing zones ranged from 20 to $32 \%$.

Amare et al., (2016) weed growth throughout the crop growth period caused a yield reduction of $72 \%$ in both cropping seasons.

Kaur et al., (2017) reported that the season long growth of weeds reduced wheat yield up to $38.5 \%$.

Pawar et al., (2017) Weeds caused 55.7 and $52.2 \%$ reduction in grain yield of wheat.

Chandra et al., (2018) the grain yield of wheat was reduced by $30.7 \%$ due to weeds.

Yadav et al., (2018) Weeds growing throughout the crop season caused $68.8 \%$ and $45.8 \%$ reduction in the grain yields. 


\section{Weed management practices}

\section{Cultural control}

Surin et al., (2013) from Bihar, reported that hand weeding at 25 DAS in wheat crop recorded higher yield attributing parameters like $31.3 \%$ higher productive tillers $/ \mathrm{m}^{2}, 5.3 \%$ higher spike length and $8.6 \%$ higher straw yield compared to weedy check.

Amare et al., (2016) manual hand weeding + $2,4-\mathrm{D}$ at $2.0 \mathrm{~kg} \mathrm{ha}^{-1}$ highest grain yield $4.3 \mathrm{t}$ $\mathrm{ha}^{-1}$ of wheat.

Safina and Absy (2017) herbicides and hand weeding twice) increases wheat yield $11.8 \mathrm{t}$ $\mathrm{ha}^{-1}$ and yield components significantly compared to weedy check.

Rasool et al., (2017) Manual hand weeding increases wheat grain yield $4.98 \mathrm{t} \mathrm{ha}^{-1}$ as compare to weedy check.

Sasode et al., (2017) Manual two hand weeding @ 30 and 60 DAS resulted in increased grain yield of Wheat $4.66 \mathrm{t} \mathrm{ha}^{-1}$.

\section{Chemical control}

Pawar et al., (2017) post-emergence application of pinoxaden $2.53 \%$ + clodinafoppropargyl $2.53 \%$ at $60 \mathrm{~g} \mathrm{ha}^{-1}$ resulted as produced highest grain yield (4.5-4.6 $\left.\mathrm{t} \mathrm{ha}^{-1}\right)$ of wheat.

Yadav et al., (2018) application of postemergence Pinoxaden + clodinafop $60 \mathrm{~g} \mathrm{ha}^{-1}$ resulted as maximum grain yield $\left(5.7 \mathrm{t} \mathrm{ha}^{-1}\right)$ of wheat crop.

Kumar et al., (2019) post-emergence application of markclodina @ $0.060 \mathrm{~kg} \mathrm{ha}^{-1}$ resulted as increased grain yield of wheat $4.2 \mathrm{t}$ $\mathrm{ha}^{-1}$.

Sareta et al., (2016) post-emergence application of mesosulfron methyl
+Idosulfuron methyl sodium at a rate of 1 lit $\mathrm{ha}^{-1}$ as results in maximum wheat grain yield 5 $\mathrm{tha}^{-1}$.

Meena et al., (2017) Post-emergence application of metsulfuron + sulfosulfuron $\left(0.003\right.$ and $\left.0.02 \mathrm{~kg} \mathrm{ha}^{-1}\right)$ results in incresed grain yield of wheat $4.98 \mathrm{tha}^{-1}$.

Singh et al., (2017) Post-emergence application of metsulfuron + clodinafop (4+ $60 \mathrm{~g} / \mathrm{ha}$ ) ready mixture applied at 25 DAS results increased grain yield of wheat $5.37 \mathrm{t}$ $\mathrm{ha}^{-1}$.

Devi et al., (2018) Post-emergence application of carfentrazone and metsulfuron-methyl (25 $\mathrm{g} / \mathrm{ha}$ ) results in increased increased grain yield of wheat $5.4 \mathrm{t} \mathrm{ha}^{-1}$.

Patil et al., (2018) hoeing at 20 DAS with combination of metasulfuron methyl @ $4 \mathrm{~g}$ a.i. $\mathrm{ha}^{-1}$ as post-emergence at $30 \mathrm{DAS}$ resulted as increased grain yield in wheat $2.9 \mathrm{t} \mathrm{ha}^{-1}$.

Chandra et al., (2018) post emergence application of isoproturon +2 , 4-D at $0.5 \mathrm{~kg}$ a.i. / ha at 30 days after sowing resulted in increased grain yield of wheat $3.8 \mathrm{t} \mathrm{ha}^{-1}$.

Kaur and kaur (2019) application of postemergence of highest dose 2, 4-D sodium salt $(500 \mathrm{~g} / \mathrm{ha})$ resulted as increased grain yield and straw yield in wheat $4.52 \mathrm{t} \mathrm{ha}^{-1}$ and $8.63 \mathrm{t}$ $\mathrm{ha}^{-1}$.

Chandra et al., (2018) post emergence application of isoproturon + 2,4-D at $0.5 \mathrm{~kg}$ a.i./ha at 30 days after sowing followed proved most economic for controlling weeds in wheat field under Jhansi conditions.

Kaur and kaur (2019) application of postemergence of highest dose2, 4-D sodium salt (500 g/ha) adversely affected growth of both the weed species at 21 DAT in wheat crop. 
Kaur et al., (2019) Pre-emergence application of pyroxasulfone at $127.5 \mathrm{~g} / \mathrm{ha}$ recorded effective control of $P$. minor of wheat crop.

Bayat and Zarger (2020) Application of postemergence of pyroxasulfone @ $120 \mathrm{~g} \mathrm{ha}^{-1}$ as resulted good control of field bindweed (Convovulas arvensis) of wheat.

Johnson et al., (2018) Pre-emergence application of pyroxasulfone @ $112 \mathrm{~g} \mathrm{ha}^{-1}$ as resulted maximum grain yield $5.47 \mathrm{t} \mathrm{ha}^{-1}$ of wheat.

Kaur et al., (2019) Pre-emergence application of pyroxasulfone at $127.5 \mathrm{~g} / \mathrm{ha}$ recorded maximum biomass and gave the highest wheat grain yield $(4.87,4.80$ and $5.43 \mathrm{t} / \mathrm{ha})$ of wheat crop.

Influence of weed management practices on weed characteristics and weed control efficiency

\section{Weed density}

Patel et al., (2017) Application of pre-mix sulfosulfuron $(75 \%)+$ metsulfuron-methyl (5\%) $32 \mathrm{~g} / \mathrm{ha}$ as post-emergence was recorded reduced the density and biomass of both monocot as well as dicot weeds of wheat crop.

Kaur et al., (2017) reported that postemergence application of pre-mixture of pinoxaden plus clodinafop at 50-60 $\mathrm{g} /$ harecorded effective control of $P$. Minor.

Kaur et al., (2017) notice that Pendimethalin (PE) $f b$ sulfosulfuron (PoE) $1.0 f b 0.018 \mathrm{~kg} / \mathrm{ha}$ $1.9 \mathrm{~g} \mathrm{~m}^{-2}$ reduced weed density in wheat field.

Shakya et al., (2017) recorded that at25 DAS minimum population of weeds $\left(1.33 / \mathrm{m}^{2}\right)$ was registered in pendimethalin $1.0 \mathrm{~kg} / \mathrm{ha}+$ metribuzin $0.018 \mathrm{~kg} / \mathrm{ha}$ in wheat crop.
Punia et al., (2017) reported that Sulfosulfuron + metsulfuron $32 \mathrm{~g} \mathrm{ha}^{-1}$ was recorded less weed density Phalaris minor $3.9 \mathrm{~m}^{-2}$ and broad leaf weed $2.9 \mathrm{~m}^{-2}$ in wheat field.

Devi et al., (2018) reported that application of pinoxaden $50 \mathrm{~g} \mathrm{ha}^{-1}+\mathrm{RM}$ of carfentrazone and metsulfuron@25 g ha ${ }^{-1}$ recorded lowest total weed density in wheat crop.

Kaur et al., (2018) Reported that the application of Pendimethalin @ $3.75 \mathrm{~L} \mathrm{ha}^{-1}$ was recorded lowest weed density of narrow leaf weeds and broad leaf weeds $\left(2.4 \mathrm{~m}^{-2}\right.$ and $2.5 \mathrm{~m}^{-2}$ ) in wheat crop.

Kumar et al., (2019) Application of Markcodina@60 $\mathrm{g} \mathrm{ha}^{-1}$ as post-emergence was recorded lowest weed weeds density of $2.2 \mathrm{~m}^{-2}$ under the wheat crop.

Meena et al., (2019) Reported in wheat field that the application of Sulfosulfuron + metsulfuron $\left(30+2 \mathrm{~g} \mathrm{ha}^{-1}\right)$ as post-emergence at 5 Week After Sowing was recorded lowest weed weeds density of $4.85 \mathrm{~m}^{-2}$.

Al-khafji et al., (2020) Reported that the application of Atlantis WG $20 \mathrm{~g} \mathrm{ha}^{-1}$ was recorded lowest weed weeds density of $12 \mathrm{~m}^{-2}$.

\section{Weed dry weight}

Shakya et al., (2017) minimum weed dry weight $11 \mathrm{~g} \mathrm{~m}^{-2}$ was recorded under the treatment at pendimethalin $0.75 \mathrm{~kg} / \mathrm{ha}$ in wheat crop.

Devi et al., (2017) noticed thattank mixed application of pinoxaden $50 \mathrm{~g} / \mathrm{ha}+\mathrm{RM}$ of carfentrazone and metsulfuron $25 \mathrm{~g} / \mathrm{ha}$ applied at 35 days after sowing (DAS) controlled weeds effectively with lower values of weed dry matter accumulation $(7.67 \mathrm{~g} / \mathrm{ha})$. 
Hundal and Dhillon (2018) noticed that application of Pendimethalin (PE) $f b$ clodinafop @ $0.75+0.06 \mathrm{~g} \mathrm{ha}^{-1}$ as was recorded lowest dry weight of Phalaris minor is $3.78 \mathrm{~g} \mathrm{~m}^{-2}$ at the time of harvesting under the wheat crop.

Kumar et al., (2018) Application of Sulfosulfuron+metsulfuron @ $32 \mathrm{~g} \mathrm{ha}^{-1}$ as post-emergence was recorded lowest weed dry weight of $2.59 \mathrm{~g} \mathrm{~m}^{-2}$ under the wheat crop.

Kaur et al., (2018) Reported that the application of Pendimethalin@3.75 L ha ${ }^{-1}$ was recorded lowest weed dry weight of narrow leaf weeds and broad leaf weeds $(3.2 \mathrm{~g}$ $\mathrm{m}^{-2}$ and $4.1 \mathrm{~g} \mathrm{~m}^{-2}$ ) in wheat crop.

Kumar et al., (2019) Application of Markcodina@60 $\mathrm{g} \mathrm{ha}^{-1}$ as post-emergence was recorded lowest weed dry weight of $2.6 \mathrm{~g}$ $\mathrm{m}^{-2}$ under the wheat crop.

Mitra and Mondal (2019) noticed that the application of metsulfuron $\left(4 \mathrm{~g} \mathrm{ha}^{-1}\right)+$ carfentrazone $\left(20 \mathrm{~g} \mathrm{ha}^{-1}\right)+$ surfactant was recorded lowest weed dry weight of $2.9 \mathrm{~g} \mathrm{~m}^{-2}$ under the wheat crop.

Ahmed et al., (2020) Reported that the application of 2, 4-D amine plus ethoxysulfuron $\left(1.2 \mathrm{~kg}\right.$ a.i. $\left.\mathrm{ha}^{-1}\right)$ applied at 10 DAS surfactant was recorded lowest weed dry weight of $12 \mathrm{~g} \mathrm{~m}^{-2}$ under the wheat crop.

\section{Weed control Efficiency}

Singh et al., (2010) reported that highest weed control efficiency (100\% and $87.3 \%)$ of wheat recorded as weed free plot followed by XDE 742 3\% OD+Intron@ $18+300 \mathrm{~g} \mathrm{ha}^{-1}$ as post-emergence.

Dhyani et al., (2010) post-emergence application of sulfosulfuron at $25 \mathrm{~g} / \mathrm{ha}$ recorded as highest weed control efficiency 94 $\%$ in wheat field.
Khokhar and Nepalia (2010) Maximum weed control efficiency $93.58 \%$ by wheat crop was in plots treated with tank mixture of isoproturon at $500 \mathrm{~g} / \mathrm{ha}+$ sulfosulfuron at 15 $\mathrm{g} / \mathrm{ha}$ as post-emergence application.

Sen et al., (2010) two hand weedings at 30 and 50 DAS resulted as maximum weed control efficiency $97.8 \%$ by wheat.

Tiwar et al., (2011) the weed control efficiency was maximum (80.4\%) in the treatment 2, 4-D $0.75 \mathrm{~kg} / \mathrm{ha}+$ isoproturon 1.0 $\mathrm{kg} \mathrm{ha}^{-1}$ at 50 DAS by wheat.

Bharat et al., (2012) post-emergence application of sulfosulfuron +2 , 4-D $25+500$ $\mathrm{g} \mathrm{ha}^{-1}$ resulted as maximum weed control efficiency $93.2 \%$ by wheat.

Kumar et al., (2012) post-emergence application of clodinafoppropargyl + metsulfuron-methyl @ 60+4 $\mathrm{g} \mathrm{ha}^{-1}$ resulted as increased weed control efficiency $84.7 \%$ by wheat.

Singh and Verma (2013) post-emergence application of carfentrazone + sulfosulfuron with surfactant at $45 \mathrm{~g} / \mathrm{ha}$ recorded as increased weed control efficiency $66.75 \%$ by wheat.

Kumari et al., (2013) Post-emergence application of Sulfosulfuron + metsulfuron 32 $\mathrm{g} \mathrm{ha}^{-1}$ resulted as increased weed control efficiency $84.5 \%$ by wheat.

Pisal et al., (2013) two hand weeding at 20 and 40 DAS resulted as increased weed control efficiency $87.87 \%$ by wheat.

Yadav and Dixit (2014) two hand weeding at 30 and 60 DAS resulted asincreased weed control efficiency $92.2 \%$ by wheat.

Vyavahare and Bhilare (2014) Post-emergence application of sulfosulfuron $16.5 \mathrm{~g} / \mathrm{ha}+2$, 4-D 
$563 \mathrm{~g} / \mathrm{ha}$ at 30 DAS resulted as maximum weed control efficiency $64.4 \%$ by wheat.

Kaur et al., (2015) post-emergence application of clodinafop $60 \mathrm{~g} \mathrm{ha}^{-1}$ and metsulfuron $4 \mathrm{~g}$ $\mathrm{ha}^{-1}$ resulted asmaximum weed control efficiency $78.1 \%$ by wheat.

Kien et al., (2016) post-emergence application of metsulfuron + sulfosulfuron @ $3 \mathrm{~g} \mathrm{ha}^{-1}+$ $20 \mathrm{~g} \mathrm{ha}^{-1}$ resulted as maximum weed control efficiency $84.75 \%$ by wheat.

Bhoir et al., (2016) Manual three hand weeding at 20, 40, 60 DAS resulted as highest weed control efficiency $97.72 \%$ by wheat.

Sudha and Biradar (2016) Sulfosulfuron + metsulfuron 25@ g ha ${ }^{-1}+4 \mathrm{~g} \mathrm{ha}^{-1}$ recorded that highest weed control efficiency $81.62 \%$ by wheat.

Kaur et al., (2017) Pendimethalin (PE) $f b$ sulfosulfuron (PoE) $1.0 \mathrm{fb} \quad 0.018 \quad \mathrm{~kg}^{-1}$ recorded that highest weed control efficiency $95.6 \%$ by wheat.

Devi et al., (2018) post-emergence application ofpinoxaden $\left(50 \mathrm{~g} \mathrm{ha}^{-1}\right)+$ ready mix of carfentrazone and metsulfuron $\left(25 \mathrm{~g} \mathrm{ha}^{-1}\right)$ recorded that highest weed control efficiency $95.09 \%$ by wheat.

Kumar et al., (2018) post-emergence application of sulfosulfuron+metsulfuron (32 $\mathrm{g} \mathrm{ha} \mathrm{h}^{-1}$ ) recorded that highest weed control efficiency $83.6 \%$ by wheat.

Kumar and Singh (2018) post-emergence application of sulfosulfuron + metsulfuronmethyl $30 \mathrm{~g} \mathrm{ha}^{-1}+2 \mathrm{~g} \mathrm{ha}^{-1}$ recorded that highest weed control efficiency $84.3 \%$ by wheat.

Kumar et al., (2019) post-emergence application of markclodina @ $60 \mathrm{~g} \mathrm{ha}^{-1}$ recorded that highest weed control efficiency $80.5 \%$ by wheat.

Meena et al., (2019) post-emergence application of sulfosulfuron + metsulfuron @ $30+2 \mathrm{~g} \mathrm{ha}^{-1}$ recorded that highest weed control efficiency $95.36 \%$ by wheat.

Mitra and Mondal (2019) post-emergence application of metsulfuron (4 $\left.\mathrm{g} \mathrm{ha}^{-1}\right)+$ carfentrazone $\left(20 \mathrm{~g} \mathrm{ha}^{-1}\right)+$ surfactant recorded that highest weed control efficiency 99\% @ 60 DAS by wheat.

The applications of pre-emergence and postemergence herbicides are successfully control weed flora in wheat field. As compare other methods of weed control chemical weed management is better control of narrow leaf and broad leaf weeds in wheat field. The applications of herbicides to reduce weed density, weed dry weight and maximum weed control efficiency are obtained.

\section{References}

Amare T., Sharma J.J, Zewdie K.2014. Effect of Weed Control Methods on Weeds and Wheat (Triticum aestivum L.) Yield. World Journal of Agricultural Research, 2(3): 124-128.

Amare. 2014. Effect of weed management methods on weeds and wheat (Triticum aestivum L.) yield. African Journal of Agricultural Research.9 ( 24), pp. 1914-1920.

Amare T, Raghavaiah C.V. and Takele Zeki. 2016. Productivity, Yield Attributes and Weed Control in Wheat (Triticum aestivum L.) as Influenced by Integrated Weed Management in Central High Lands of Ethiopia, East Africa. Advances in Crop Science and Technology, 4 (1): 206.

Ahmed S., Alam M.D.J., Awan T.H., Chauhan B.S. 2020. Effect of application 
timings and tank mixture of herbicides on weed suppression, crop growth and yield of wheat. Journal of Research in Weed, 3 (2): 214-229.

Al-Khafji A.H., Mohammed N.I. and AlWagaa A.H. 2020. Effect of Different Herbicides on Weed Control and The Growth Characteristics of Wheat (Triticum aestivum L.) variety ipa 95. Plant Archives, 20(1):556-561.

Ali Hussein Al-Khafji, Nabeel I. Mohammed and Adnan Hussein Al-Wagaa, 2020. Effect of Different Herbicides on Weed Control andthe Growth Characteristics of WHEAT (TRITICUM AESTIVUM L.) Variety IPA 95. Plant Archives, 20(1): 556561.

Bayat M., Zarger M. 2020. Field Bindweed Convolvulas arvensis and Winter Wheat Responses to Post Herbicides Apllication. Journal of Crop Science and Biotechnology, 23: 149-155.

Bharat R, Kachroo D, Sharma R, Gupta G.M, and Sharma A.K. 2012. Effect of different herbicides on weed growth and yield performance of wheat. Indian Journal of Weed Science 44(2): 106-109.

Bhoir SD, Bhondave TS, Raundal P.U. and S. S. Bhondave SS. 2016. Integrated Weed Management in Wheat. J. Agric. Res. Technol, 41 (2): 189-195.

Chandra S., Kumar1 S., Acharya S., Kumar P. and Tyagi S. 2018. Effect of Different Weed Management Practices on Growth and Yield of Wheat and Associated Weeds. Int. J. Curr. Microbiol. App. Sci, 7: 3859-3865.

Devi S., Hooda V.S., Singh J. and Kumar A. 2017.Effect of planting techniques and weed control treatments on growth and yield of wheat. Journal of Applied and Natural Science, 9 (3): 1534 -1539.

Devi S., Hooda V.S., Kamboj N.K. and Singh J. 2018. Bioefficacy of Herbicides in
Relation to Planting Techniques in Wheat. Chem Sci Rev Lett, 7(25): 7782.

Dhyani V.C., Misra R.D., Prakash A. and Chaturvedi S. 2010. Effect of different

Herbicides on weeds and yield of zero tilled wheat. Indian Journal of Weed Science 42(1\&2): 42-47.

Galon L., Basso F.G.M., Chechi L., Pilla T.P., Santin C.O, Maico Andre Michelon

BagnaraM.A.M, Franceschetti M.B., Castoldi C.T., Perin G.F., Forte C.T... 2019. Weed interference period and economic threshold level of ryegrass in wheat. Bragantia, Campinas, 78(3):409-422.

Hundal R.K. and. Dhillon B.S. 2018. Control of Phalaris minor with sequential application of pre- and postemergence herbicides and herbicide combinations in wheat Indian Journal of Weed Science,50(4): 351-354, 2018.

Hussain S. et al., 2015. Interference and economic threshold level of little seed canary grass in Wheat under different sowing times. Environ Sci Poll Re, 22:441-9.

Jabran K., Ali A., Sattar A., Ali Z., Yaseen M., Hussain M., Iqbal J. And Munir M.K. 2012 Cultural, mechanical and chemical weed control in wheat, CROP \& ENVIRONMENT, 3(1-2): 5053.

Johnson E.N., Wang Z., Geddes C.M., Coles K., Hamman B. and Beres B.L.2018. Pyroxasulfone Is Effective for Management of Bromus spp. in Winter Wheat in Western Canada. Weed Science Society of America, 32:739748.

Kaur T., Bhullar M.S. and Walia U.S. 2015. Bio-efficacy of ready-mix formulation of Clodinafop-propargyl + metsulfuron for control of mixed weed flora in wheat. Indian Journal of Weed Science 47(2): 121-124. 
Kaur S., Kaur T. and Bhullar M. 2017. Control of mixed weed flora in wheat with sequential Application of pre- and post-emergence herbicides. Indian Journal of Weed Science 49(1): 29-32.

Kaur T., Bhullar M.S. and Kaur S. 2019. Control of herbicide resistant Phalaris minor by Pyroxasulfone in wheat. Indian Journal of Weed Science 51(2): 123-128.

Kaur A. and Kaur N. 2019. Effect of sublethal doses of 2, 4-D sodium salt on physiology and seed production potential of wheat and associated dicotyledonous weeds. Indian Journal of Weed Science 51(4): 352-357.

Khan M., Haq N. 2002. Wheat crop yield loss assessment due to weeds. Sarhad J Agric. 18:443-8.

Khokhar A.K. and Nepalia V. 2010. Effect of Herbicides and Nutrient Management on Weed Flora, Nutrient Uptake and Yield of Wheat (Triticum aestivum) under Irrigated Conditions. Indian J. Weed Sci. 42 (1 \& 2): 14-18.

Kien P.T., Massey J.X., Mundra S.L. and Kalita S. 2016. Effect of weed management Practices on productivity of wheat. Indian Journal of Weed Science 48(4): 445-446.

Kumar S., Angiras N.N. and Rana S.S. 2011. Bio-efficacy of clodinafop propargyl + Metsulfuron methyl against complex weed flora in wheat. Indian Journal of Weed Science 43 (3\&4): 195-198.

Kumar S., Singh R., Shyam R. and Singh V.K. 2012. Weed dynamics, nutrient removal and yield of wheat as influenced by weed management practices under valley conditions of Uttarakhand. Indian Journal of Weed Science 44(2): 110-114.

Kumari A., Kumar S., Singh B. and Dhaka A. 2013. Evaluation of herbicides alone and in Combination for weed control in wheat. Indian Journal of Weed
Science 45(3): 210-213.

Kumar M., Ghosh D. and Singh R. 2018. Effect of crop establishment and weed management Practices on growth and yield of wheat. Indian Journal of Weed Science 50(2): 129-132.

Kumara S., Ranaa S.S., Badiyalaa D., Kumara S., Sharma N.. 2019. Bioefficacy of post-emergence herbicide PrioxofopPropanyl (Markclodina) against weeds in wheat. Journal of Research in Weed Science, 2: 141- 148.

Malik R.S., Yadav A. and Kumari R. 2013. Ready-mix formulation of clodinafoppropargyl + metsulfuron-methyl against complex weed flora in wheat. Indian Journal of Weed Science 45(3): 179-182.

Meena V., Kaushik M.K., Dotaniya M.L., Meena B.P. and Das H. 2019. Bioefficacy of readi-mix herbicides on weeds and productivity in late-sown wheat. Indian Journal of Weed Science 51(4): 344-351.

Meena V., Kaushik M.K., Meena S.K., Bhimwal J.P. and Chouhan B.S. 2017. Influence of pre and post- emergence herbicide application on weed growth and nutrient removal in wheat (Triticum aestivum L.). Journal of Pharmacognosy and Phytochemistry, 6(6): 2413-2418.

Mitra B., Barman R. and Mondal T. 2019. Control of broad-leaved weeds in wheat under eastern sub-Himalayan plains. Indian Journal of Weed Science 51(1): 27-31.

Oad F., Siddiqui M., Buriro U. 2007. Growth and yield losses in Wheat due to Different Weed Densities. Asian Journal of Plant Sciences, 6 (1): 173176.

Pawar J., Singh R., Neelam, Kabdal P., Prabhakar D. and Kumar S. 2017. Optimization rate of pinoxaden + clodinafop-propargyl for weed control 
in wheat. Indian Journal of Weed Science 49(2): 136-138.

Patil S.K., Suryavanshi G.B., Patil J.B. and Kusale S.P. 2018. Effect of integrated weed Management on growth, yield and economics of wheat (Triticum aestivum L.). International Journal of Chemical Studies 6(6): 51-54.

Pisal R.R., Surve V.H., Jathar S.C. and Sagarka B.K. 2013. Impact of Weed Control Treatments on Weed Flora, Nutrient Uptake by Weeds and Wheat crop. Agric. Sci. Digest., 33 (1): 47 51.

Punia S.S., Singh S., Yadav D.B., Sindhu V.K. and Duhan A. 2017.Abundance, distribution And diversity of weeds in wheat in Haryana, Indian Journal of Weed Science 49(2): 187-190.

Rasool R., Bhullar M.S. and. Gill G.S. 2017. Growth stage of Phalaris minor Retz. And wheat Determines weed control and crop tolerance of four postemergence herbicides. Spanish Journal of Agricultural Research 15(1): 21719292.

Safina. S and Absy R. 2017. Broadleaf Weed Control with some Recent Postemergence Herbicides in Bread wheat (Triticum aestivum L.) in Egypt. Egypt.J.Agron. 39(1): 41-50.

Saha M., Banerjee H. and Pal S. 2016. Relative efficacy of herbicides in wheat. Indian Journal of Weed Science 38(1\&2): 127-128.

Sahu R., Sharda K., Kumar D. and Mandal S.K. 2018. Weed population, weed biomass and Grain yield of wheat as influenced by herbicides application. Indian Journal of Weed Science 50(3): 302-304.

Sandhu B.S. and Dhaliwal N.S. 2016. Chemical weed management to increase productivity of wheat. Indian Journal of Weed Science 48(4): 381383.
Sareta H., Worku W. and Begna B. 2016. Economics of Herbicide Weed Management in Wheat in Ethiopia. African Crop Science Journal, 24(1):109 - 116.

Sasode D.S., Gupta V., Joshi K., Arora A., Dixit J.P. and Panse R. 2017. Management of Diverse weed flora of wheat by herbicide combinations. Indian Journal of Weed Science.49 (2): 147-150.

Sen D., Singh R. and Shyam R. 2010. Efficacy of tillage and weed management practices On weed infestation and yield of wheat. Indian Journal of Weed Science 42(1\&2): 57-61.

Shakya N., Mahor S., Chicham S., Paliwal D.K., Shakya A. 2017. Different Combination Herbicides Weed Management Practices on Wheat [Triticum aestivum (L.)]. Bulletin of Environment, Pharmacology and Life Sciences, 6 [1]: 374-379.

Singh V.P., Dhyani V.C., Singh S.P., Kumar A., Singh M.K. and Tripathi N. 2010. Bioefficacy of Pyroxsulam (XDE-742) for Weed Control in Wheat (Triticum aestivum L.). Indian J. Weed Sci. 42 (1 \& 2): 95-97.

Singh R.K., Verma S.K. and Singh R.P. 2013. Bio-efficacy of carfentrazone-ethyl + sulfosulfuron in wheat. Indian Journal of Weed Science 45(4): 243-246.

Singh, R.M. and Saxena, R. 2013. Effect of perdimethation alone or mixture with isoprotuon or sulfosulfuron on Phalaris minor density and yield of wheat. Research on Crop 1(1):5-8.

Singh, S., Singh S., Sharma, S.D., Punia, S.S and Singh, H. 2013. Performance of tank mixture of metribuzin with clodinafop and fenoxaprop for the control of mixed weed flora in wheat. Indian Journal of Weed Science 37(1\&2): 9-12.

Singh A.P., Bhullar M.S., Yadav R. and 
Chowdhury T. 2015. Weed management in zero-till wheat. Indian Journal of Weed Science 47(3): 233239.

Singh P.K., Sondhia S., Dubey R.P., kumar S., Kumar B., Gharde Y. and Choudhary V.K. 2017. Adoption and impact assessment of weed management technologies in wheat and greengram under conservation agriculture system in central India. Indian Journal of Weed Science 49(1): 23-28.

Singh P., Kewat M.L., Sharma A.R., Sapre N. 2017. Tillage and weed management effect on productivity of wheat under soybean-wheat-greengram cropping system in conservation agriculture. Indian Journal of Weed Science 49(3): 226-230

Sudha T., Babu R. and Biradar D.P. 2016. Weed management through tank mix and premix herbicides in wheat. Indian Journal of Weed Science 48(4): 378380.

Surin, S.S., Singh, M.K., Upasani, R.R., Thakur, R. and Pal S.K. 2013. Weed management in Rice (Oryza sativa)Wheat (Triticum aestivum) cropping system under conservation tillage. Indian Journal ofAgronomy 58(3): 288- 29.
Tiwari D. and Kewat M.L. 2010. Impact of tillage and weed control practices on weed flora and yield of wheat in direct seeded rice-wheat cropping system. Indian Journal of Weed Science 42(1\&2): 104-106.

Vyavahare S.B. and Bhilare R.L. 2014. Effect of post-emergence herbicides on weeds and Productivity of wheat. Indian Journal of Weed Science 46(4): 386388.

Yadav N.S. and Dixit A. 2014. Bioefficacy of some herbicides and their mixtures against Complex weed flora in wheat. Indian Journal of Weed Science 46(2): 180-183.

Yadav D.B., Singh N., Duhan A., Yadav A. and Punia S.S. 2018. Penoxsulam + cyhalofop-Butyl (premix) evaluation for control of complex weed flora in transplanted rice and its residual effects in rice-wheat cropping system. Indian Journal of Weed Science 50(4): 333-339.

Yadav D.B., Yadav A. and Punia S.S. 2019. Long-term effects of green manuring and herbicides on weeds and productivity of the rice-wheat cropping system in North-Western India. Indian Journal of Weed Science 51(3): 240245.

\section{How to cite this article:}

Laxman Somanath Vyvahare and Pratap Jambuvant Khose. 2021. Studies on Chemical Weed Control in Wheat (Triticum aestivum L.) - A Review. Int.J.Curr.Microbiol.App.Sci. 10(02): 1982-1992. doi: https://doi.org/10.20546/ijcmas.2021.1002.238 